\title{
Interactie tussen EU-instellingen: het Europees Parlement, de Raad en het wetgevingsbeleid van de Europese Commissie ${ }^{*}$
}

\author{
T.J.A. van Golen
}

\section{Introductie}

In mei 2015 werd de Better Regulation Agenda gepubliceerd, het geheel van documenten die tezamen het wetgevingsbeleid van de Europese Commissie (hierna: Commissie) vormen. ${ }^{1}$ Dit was niet de eerste keer dat de Commissie het wetgevingsbeleid presenteerde aan de buitenwereld. ${ }^{2}$ Wel werd in 2015 voor het eerst één samenhangend beleidsdocument onder de naam Better Regulation Guidelines gepresenteerd, ${ }^{3}$ in plaats van losse, afzonderlijke richtsnoeren per instrument. ${ }^{4}$ In dit document werd ook meer nadruk gelegd op de idee van een cyclisch wetgevingsproces. ${ }^{5}$ Door deze nadruk op een cyclisch wetgevingsproces zou er een betere aansluiting van de fases van onderzoek vooraf en evaluatie achteraf moeten ontstaan. Hoe die koppeling tussen de twee instrumenten van de Commissie,

* De auteur schrijft deze bijdrage op persoonlijke titel. Hij dankt graag de redactieleden van RegelMaat en André Berends voor de nuttige opmerkingen bij de eerdere versies van dit artikel.

1 Alle documenten zijn te vinden op ec.europa.eu/commission/priorities/democratic-change/ better-regulation_en, bezocht op 26 september 2020 .

2 Zie bijv. R.A.J. van Gestel, 'Beter en minder wetgeven in Europea', RegelMaat 2005, afl. 3, p. 95-108; A.C.M. Meuwese, 'Impact assessments in de Europese Commissie', RegelMaat 2005, afl. 3, p. 109-114; W.J.M. Voermans, 'Smart Regulation - Slim geregeld?, RegelMaat 2010, afl. 5, p. 272-274.

3 Waar voorheen elk instrument dat de Commissie gebruikt een eigen guideline had, die niet op elkaar aansloten, zijn deze nu allemaal samengevoegd tot één coherent document, de Better Regulation Guidelines en begeleidende Toolbox voor de technische uitwerking. De Better Regulation Guidelines en Toolbox uit 2017 zijn te vinden als SWD(2015)0111 (Guidelines) en op ec.europa.eu/smart-regulation/guidelines/docs/br_toolbox_en.pdf (Toolbox), bezocht op 26 september 2020. De nieuwe Guidelines uit 2017 zijn te vinden als SWD(2017)0350, en op ec.europa.eu/info/sites/info/files/better-regulation-toolbox_2.pdf bevindt zich de Toolbox-versie van 2017, bezocht op 26 september 2020.

4 Zie hierover ook T.J.A. van Golen, 'Better Regulation 2.0 in de Europese Unie: het nieuwe Interinstitutioneel Akkoord en de nieuwe Better Regulation-richtlijnen voor de Europese Commissie', RegelMaat 2016, afl. 4, p. 295-308.

5 In tegenstelling tot een lineair proces, waar het eindpunt is bereikt als de wetgeving is gepubliceerd of na een aantal jaar is geëvalueerd, is bij een cyclisch wetgevingsproces de evaluatie geen eindpunt, maar juist een beginpunt van een volgend traject omdat de evaluatie dient als informatie voor de volgende impact assessment vooraf. 
impact assessments ${ }^{6}$ vooraf en wetsevaluaties ${ }^{7}$ achteraf, precies vorm moest krijgen was echter nog niet geheel duidelijk. Daarnaast zou de totstandbrenging van die koppeling wellicht minder eenvoudig zijn dan van tevoren gedacht. ${ }^{8}$

In mijn proefschrift ${ }^{9}$ heb ik getracht te bezien in hoeverre deze koppeling tussen impact assessment en wetsevaluaties al gelegd is in het Europese wetgevingstraject. Ik heb daarbij expliciet gekeken in hoeverre de impact assessments en wetsevaluaties nu gebruikt worden in de wetgevingstrajecten van de EU. Op basis van literatuuronderzoek bleek dat om deze koppeling te kunnen laten slagen er drie fundamentele vereisten zijn waaraan het wetgevingsproces moet voldoen: (a) deze twee instrumenten moeten beschikbaar zijn voor gebruik, (b) deze instrumenten moeten compatibel met elkaar zijn, anders gaat de doorgifte van informatie mis, en (c) deze koppeling moet systematisch over meerdere trajecten gelegd worden om leereffecten te genereren. ${ }^{10}$ Uit het onderzoek kwam, kort samengevat, naar voren dat met name de vereisten onder a en c, beschikbaarheid en de systematische koppeling, nog niet geheel gewaarborgd zijn in de wetgevingscyclus van de EU. ${ }^{11}$ Dit is deels een gevolg van keuzes in het verleden. Zeker in het begin van het wetgevingsbeleid heeft de Commissie veel meer aandacht gegeven aan impact assessments vooraf dan aan evaluaties achteraf. Dit betekent dat het probleem van ontbrekende evaluaties voor langere tijd opspeelt, zelfs nadat sinds ongeveer 2010 meer aandacht hiervoor komt. Daarnaast zijn het Europees Parlement en de Raad van Ministers (hierna: Parlement en Raad) niet altijd even betrokken geweest bij het wetgevingsbeleid. Weliswaar is in 2003 een Interinstitutioneel Akkoord over Beter Wetgeven gesloten, ${ }^{12}$ maar dat betekende in de praktijk niet dat er een vergaande samenwerking op dit gebied tot stand kwam. De Commissie bleef de primair verantwoordelijke voor dat wetgevingsbeleid en dat heeft zij door de loop der jaren heen ook steeds meer uitgebouwd. De

6 Impact assessments zijn een effectbeoordeling voorafgaande aan wetgeving en andere initiatieven waar er, bezien vanuit het probleem dat geconstateerd is en opgelost moet worden, wordt nagegaan wat de effecten (o.a. milieu, sociaal, en economisch) zouden zijn van verschillende beleidsopties.

7 Wetsevaluaties onderzoeken hoe wetgeving heeft gefunctioneerd, en leggen daarbij ook de koppeling naar de verwachtingen zoals beschreven in de effectbeoordeling vooraf. Beide instrumenten hebben effectiviteit, efficiëntie, coherentie, relevantie en EU-toegevoegde waarde als de vijf belangrijkste criteria.

$8 \quad$ Van Golen 2016, p. 306-307.

9 T.J.A. van Golen, Assessing the European Commission's legislative cycle: The problems of linking exante impact assessments and ex-post legislative evaluations, Tilburg: Tilburg University 2020. De verdediging stond gepland op 20 maart 2020, maar is vanwege Covid-19 verplaatst naar 6 juli 2020. Het proefschrift is te downloaden op research.tilburguniversity.edu/en/publications/ assessing-the-european-commissions-legislative-cycle-the-problems, bezocht op 26 september 2020.

10 Van Golen 2020, p. 28-33.

11 Van Golen 2020, p. 92-93.

12 Interinstitutioneel Akkoord 'Beter Wetgeven', OJ C 321, 31 december 2003, p. 1-5. 
Better Regulation Agenda uit 2015 is de meest recente versie van dit wetgevingsbeleid. ${ }^{13}$

Tijdens mijn eigen onderzoek van het wetgevingsbeleid is op Europees niveau doorgewerkt aan dit onderwerp. Volgens het Interinstitutioneel Akkoord is goede wetgeving een gedeelde verantwoordelijkheid van de drie centrale EUinstellingen. ${ }^{14}$ Dat betekent dat naast de Commissie ook het Parlement en de Raad zich hiermee bezig hebben gehouden. In dit artikel zal ik een aantal ontwikkelingen bespreken bij de drie instellingen met betrekking tot dit wetgevingsbeleid, en ik zal daarbij specifiek de koppeling tussen impact assessments en wetsevaluaties als focus gebruiken. Allereerst bespreek ik een aantal samenwerkingsverplichtingen voor de Commissie, het Parlement en de Raad die vastgelegd zijn in het Interinstitutioneel Akkoord uit 2016. Daarna zal ik bezien wat het Parlement en de Raad doen met impact assessments en wetsevaluaties om te bezien hoe deze instellingen bijdragen aan het wetgevingsbeleid, los van de gebruikelijke wetgevingsprocedure. Vervolgens bespreek ik de rol van de Regulatory Scrutiny Board (RSB), het kwaliteitsbewakende semionafhankelijke orgaan van de Commissie dat verantwoordelijk is voor de kwaliteit van de impact assessments en wetsevaluaties. De RSB heeft sinds 2015 de taak gekregen om zowel impact assessments als wetsevaluaties te beoordelen en hierdoor te kwaliteit te verhogen. De vraag is natuurlijk in hoeverre dat gelukt is. Ook de Commissie zelf heeft onderzoek laten doen naar haar eigen wetgevingsbeleid. Ik bespreek kort de resultaten van deze onderzoeken en trek een vergelijking met de resultaten uit mijn proefschrift. Ik haal daarna kort aan welke veranderingen er te verwachten zijn op basis van de informatie die nu bekend is over het wetgevingsbeleid onder de Commissie-Von der Leyen. Ten slotte sluit ik af met een conclusie.

\section{Veranderingen sinds het begin van het Interinstitutioneel Akkoord 2016}

Met het aannemen van het nieuwe Interinstitutioneel Akkoord in 2016 bevestigen de drie EU-instellingen dat goede regelgeving niet slechts een Commissieaangelegenheid is, maar een gedeelde verantwoordelijkheid van Commissie, Raad en Parlement. ${ }^{15} \mathrm{Om}$ tot deze goede regelgeving te komen hebben de instellingen een aantal afspraken hieromtrent vastgelegd. ${ }^{16}$ Hierna ga ik vooral in op de

Over deze versie uit 2015 is al een aantal nationale en internationale artikelen verschenen. Voor wat betreft Nederlandse artikelen, zie L.A.J. Senden, 'Het Commissiepakket "betere regelgeving voor betere resultaten" en het nieuwe Interinstitutioneel Akkoord beter wetgeven: Too little, too late?', NtER 2016, afl. 6, p. 211-220 en Van Golen 2016. Voor internationale artikelen, zie bijv. A. Alemanno, 'How Much Better is Better Regulation? Assessing the Impact of the Better Regulation Package on the European Union - A Research Agenda', European Journal of Risk Regulation 2015 (6), afl. 3, p. 344-356 en C.M. Radaelli, 'Halfway Through the Better Regulation Strategy of the Juncker Commission: What Does the Evidence Say?', Journal of Common Market Studies 2018, afl. 56, p. 85-95.

14 Zie over goede wetgeving ook de bijdrage van Van den Brink in dit themanummer.

15 Zie overweging 2 van het IIA 2016.

16 Zie voor een aantal overwegingen hierover Van Golen 2016, p. 302-303 en Senden 2016, p. 214. 
afspraken over gezamenlijke programmering en een gezamenlijk portaal voor wetgeving.

\subsection{Meerjarige en jaarlijkse gezamenlijke programmering van wetgevingsprioriteiten}

De programmering van jaarlijkse en meerjarige wetgevingsprioriteiten is een gedeelde taak van de drie EU-instellingen, waarbij zij besluiten welke wetgeving een prioritaire behandeling krijgt. De meerjarige programmering was vanwege het aantreden van de Commissie-Juncker voor het ingaan van het nieuwe Interinstitutioneel Akkoord unilateraal door de Commissie bepaald door tien politieke prioriteiten vast te stellen. ${ }^{17}$ Langs deze lijnen worden ook de jaarlijkse programmeringen opgemaakt die elk jaar in het werkprogramma van de Commissie verschijnen. ${ }^{18}$ De specifieke wetgevingsdossiers zijn opgenomen in het jaarlijkse programma van de Commissie sinds $2016 .{ }^{19}$ Sinds eind 2016 is aan het werkprogramma een gezamenlijke verklaring toegevoegd waarin de drie instellingen vastleggen welke wetgevingsdossiers voorrang dienen te krijgen bij de behandeling in het Parlement en de Raad. ${ }^{20}$ In de verklaring van 2017 werd weliswaar een aantal dossiers genoemd, maar pas bij de verklaring van 2018/2019 is een werkdocument toegevoegd met daarin specifiek de tot prioriteit verklaarde dossiers. ${ }^{21}$ Een nadeel van dit document is dat het alleen een beschrijving van het voorstel vermeldt, maar geen dossier- of documentnummer, waardoor het lastiger is om te herleiden of bepaalde voorstellen ook in het werkprogramma te vinden zijn. ${ }^{22}$ In de vorige Annexen met prioriteitswetgeving in de werkprogramma's van de Commissie uit 2016 en 2018 waren zowel dossier- als documentnummers van de voorstellen opgenomen. In het werkprogramma van 2020 is deze informatie weer

17 Zie voor een overzicht ec.europa.eu/commission/sites/beta-political/files/political-guidelinesshort_en.pdf, bezocht op 26 september 2020. De commissie-Von der Leyen heeft zes prioriteiten, zie ec.europa.eu/commission/sites/beta-political/files/political-guidelines-next-commis sion_en.pdf, bezocht op 26 september 2020.

18 Zie voor het overzicht ec.europa.eu/info/publications/european-commission-work-program me_en, bezocht op 26 september 2020.

19 De eerste versie is nog vrij mager met slechts 18 dossiers (COM(2015)0610 Annex 3), in de versie voor het werkprogramma van 2019 staan al 188 wetgevingsdossier die prioriteit hebben (COM(2018)0800, Annex 3).

20 Zie ec.europa.eu/commission/sites/beta-political/files/joint-declaration-legislative-priorities2017-jan2017_en.pdf voor de Joint Declaration van 2017, en ec.europa.eu/commission/sites/ beta-political/files/joint-declaration-eu-legislative-priorities-2018-19_en.pdf voor de Joint Declaration van 2018/2019, beide bezocht op 26 september 2020. De Joint Declaration van 2018/2019 behelst ook een Working Document waarin specifieker staat opgeschreven welke wetgevingstrajecten prioriteit krijgen. Zie volgende voetnoot.

21 ec.europa.eu/commission/sites/beta-political/files/working-document-joint-declarationlegislative-priorities-2018-19_en.pdf, bezocht op 26 september 2020.

$22 \mathrm{Na}$ het nalopen van de twee werkprogramma's uit 2018 en 2019 en wat puzzelwerk in vergelijking met dit werkdocument is te zien dat van de 75 prioriteitsdossiers uit de gezamenlijke verklaring er 58 dossiers in het werkprogramma van de Commissie van 2018 staan en 40 in het werkprogramma van 2019 te vinden zijn. Een enkel voorstel stamt nog uit het werkprogramma van 2017 (voorstel voor een verordening over bescherming tegen gedumpte import en bescherming tegen gesubsidieerde import). Een ander item is 'Proposals to pursue the deepening of the Economic and Monetary Union', maar welke voorstellen hier specifiek onder vallen is niet duidelijk. 
te vinden, wat de overzichtelijkheid ten goede komt. ${ }^{23}$ Verder loopt de indeling van de thema's in de gezamenlijke verklaring niet gelijk met de tien prioriteiten die worden aangehouden in de werkprogramma's van de Commissie, hetgeen ook voor een lastigere vergelijking zorgt tussen de documenten. ${ }^{24}$ Wellicht is dit een aandachtspunt voor de voorgestelde monitoring van deze gezamenlijke verklaring die in de versie van 2018/2019 zal worden opgenomen. ${ }^{25}$ De gezamenlijke verklaring voor 2020 van de drie instellingen welke wetgeving prioriteit krijgt, is nog niet bekend gemaakt. Wel heeft het Europees Parlement de voorstellen rondom het Meerjarig Financieel Kader ${ }^{26}$ en de reactie op de Covid-19-pandemie aangemerkt als prioriteiten in 2020. ${ }^{27}$ Ook de Europese Commissie heeft hiervoor een wijziging aangebracht in haar werkprogramma, waarbij een aantal initiatieven vertraagd wordt of juist versneld wordt uitgevoerd naargelang deze kunnen bijdragen aan herstel in en na de Coronacrisis. ${ }^{28}$

\subsection{Gezamenlijk portaal voor wetgeving en trilogen}

Een ander punt dat nog in ontwikkeling is, is het gezamenlijke portaal voor wetgeving waartoe de drie EU-instellingen zich gecommitteerd hebben in de artikelen 38 en 39 uit het Interinstitutioneel Akkoord. Dit gezamenlijke portaal zou moeten zorgen voor een betere transparantie van het wetgevingsproces, inclusief een beter zicht op trilogen. Deze informele wetgevingsoverlegmomenten blijven nu nog buiten het zicht van het publiek en grote delen van het Europees Parlement. ${ }^{29}$ De vraag is hoe dit gezamenlijke portaal zou moeten bijdragen aan het zichtbaarder maken van wat in een triloog wordt afgesproken. Daarnaast is de vraag of dit portaal komt ter vervanging van alle verschillende portalen, of daar nog eens bovenop komt. Dat laatste zou de overzichtelijkheid niet ten goede komen. Op dit moment hebben de drie instellingen van de EU elk een eigen

23 Commission Work Programme 2020, $\operatorname{COM}(2020) 0037$, p. 26-38.

24 De werkprogramma's bevatten tien thema's; de twee gezamenlijke verklaringen bevatten zeven thema's en een aantal important issues. Overigens is het interessant om te zien dat een aantal thema's van rang verschoven zijn in vergelijking tussen 2017 en 2018/2019. Zo was de volgorde in 2017: (1) groei, banen en investeringen, (2) de sociale dimensie van de EU, (3) veiligheid van de burger, (4) hervorming van het migratiebeleid, (5) digitale interne markt en (6) Energie Unie en klimaatbeleid. In 2018/2019 is de volgorde: (1) veiligheid, (2) migratie, (3) groei, (4) sociaal, (5) digitaal, (6) energie en (7) democratie.

25 Enige specificatie wordt niet geboden. In het IIA is ook een monitoringregeling opgenomen (in art. 50) voor het gehele akkoord. De Interinstitutional Coordination Group, waarin overleg over deze monitoring plaatsvindt, is niet openbaar en enige informatie hierover is maar spaarzaam beschikbaar.

26 Wellicht beter bekend onder de Engelse afkorting MFF (Multi-annual Financial Framework), wat de zevenjarige begroting van de Europese Unie is.

27 oeil.secure.europarl.europa.eu/oeil/themes/list.do, bezocht op 26 september 2020 .

28 Zie ec.europa.eu/info/publications/2020-commission-work-programme-key-documents_en, bezocht op 26 september 2020. Met name in de Annex waarin nieuwe initiatieven worden besproken, is aangegeven door de Commissie welke dossiers al dan niet vertraagd zijn.

29 G.J. Brandsma, 'Transparency of EU informal trilogues through public feedback in the European Parliament: promise unfulfilled', Journal of European Public Policy (26) 2019, afl. 10, p. 1464-1483. 
portaal ${ }^{30}$ en is veel ook te vinden via het algemene EUR-LEX, ${ }^{31}$ dat bestierd wordt door het Publications Office van de EU. ${ }^{32}$ Tijdens mijn proefschriftonderzoek ondervond ik al problemen doordat de informatie op bijvoorbeeld EUR-LEX en die op het Legislative Observatory van het Parlement niet compleet gelijk waren. ${ }^{33}$ Een extra portaal zou deze informatieverwarring alleen maar vergroten. Het lijkt mij daarom zaak dat dit gezamenlijke portaal de functie overneemt van alle losse portalen, zodat er maar één plek is waar documenten in digitale vorm verschijnen. ${ }^{34}$ Daarnaast is het goed om duidelijke afspraken te maken over wanneer iets wel of niet wordt opgenomen in het gezamenlijke portaal. Tijdens mijn promotieonderzoek werd bijvoorbeeld duidelijk dat EUR-LEX alleen documenten opneemt als deze direct te koppelen zijn aan een COM-document van de Commissie. Sommige documenten worden via een andere procedure (DTS) door één enkele Eurocommissaris vastgesteld en zijn daardoor niet altijd op EUR-LEX te vinden, maar wel op de Commissiewebsite. Een goed voorbeeld hiervan is de evaluatie van zes richtlijnen met betrekking tot consumentenbescherming. ${ }^{35}$ Deze evaluatie, fitness check ${ }^{36}$ genoemd, is uiteraard wel degelijk te koppelen aan de wetgeving zelf. Echter, omdat dit document niet gekoppeld kan worden aan een specifiek communicatiedocument, is dit werkdocument niet opgenomen in EUR-LEX, terwijl het voor de wetgeving in kwestie wel een relevant document is. Ook in het Legislative Observatory van het Parlement is dit document bij geen enkele van de zes richtlijnen terug te vinden als 'follow-up'. ${ }^{37}$ Hierdoor is de koppeling tussen de wetgeving (en bijbehorende impact assessment) en de evaluatie of fitness check van deze wetgeving minder duidelijk te maken. ${ }^{38}$ Zaak is om de structuur van een alomvattend portaal zorgvuldig te doordenken en dan keuzes

30 Zo heeft de Commissie een register voor alle documenten (ec.europa.eu/transparency/regdoc), de Raad een eigen register (consilium.europa.eu/en/documents-publications) en het Parlement zijn eigen Legislative Observatory (oeil.secure.europarl.europa.eu/oeil/home/home.do), waar bijna alles te vinden is. Alle bezocht op 26 september 2020.

31 eur-lex.europa.eu, bezocht op 26 september 2020.

32 Dit onderdeel heeft tevens de verantwoordelijkheid voor de EU Publications-website (publications.europa.eu/en/web/general-publications/publications) het Open Data-portaal (data.europa.eu/euodp/en/data) en CORDIS, de database voor onderzoek in de EU (cor dis.europa.eu). Alle bezocht op 26 september 2020.

33 Zo waren in sommige wetgevingsdossiers ontbrekende gegevens, verkeerde gegevens, verkeerde koppelingen of foutieve nummeringen te vinden. Tijdens het proefschrifttraject heb ik daarom meerdere malen EUR-LEX gecontacteerd om deze informatie te laten wijzigen.

34 Een euvel dat bijv. ook binnen de Commissie nog altijd plaatsvindt, waarbij documenten niet in het register te vinden zijn (of op EUR-LEX), maar bijvoorbeeld wel op de website van de individuele DG's.

$35 \operatorname{SWD}(2017) 0209$.

36 Een fitness check wordt in de Better Regulation Guidelines omschreven als 'a comprehensive evaluation of a policy area that usually addresses how several related legislative acts have contributed (or otherwise) to the attainment of policy objectives' en is daardoor breder dan een evaluatie, die vaak slechts één richtlijn of verordening als object van studie heeft. Zie SWD(2017)0330, p. 8.

37 In afgeronde wetgevingstrajecten wil het Parlement nog wel eens follow-up documenten toevoegen om te laten zien wat een nieuwe ontwikkeling is met betrekking tot de reeds vastgestelde wetgeving.

38 Naast procedurele aspecten spelen er ook inhoudelijke aspecten bij deze evaluatie. Zie hiervoor de bijdrage van Van Schagen in dit themanummer. 
te maken, zodat alle instellingen het portaal op dezelfde manier gebruiken, met dezelfde formats en dezelfde ideeën. Dit vergt wellicht een grote omslag in (minstens twee van) de EU-instellingen, maar zou voor de informatievoorziening naar buiten toe wel een grote verbetering opleveren ten opzichte van de fragmentarische systemen die elke instelling nu zelf onderhoudt. Het zou tevens de mogelijkheid bieden om met behulp van de huidige inzichten omtrent informatiegebruik en visualisatie keuzes te maken die het Europese besluitvormings- en wetgevingsproces zo helder en duidelijk mogelijk weergeven. Naar mijn idee is een goede koppeling van de impact assessment, de resulterende wetgeving en de uiteindelijke wetsevaluatie daar een wezenlijk onderdeel van. De (technische) gesprekken over dit gezamenlijke portaal zijn nog volop aan de gang, aldus de voortgangsdocumenten van de Raad over de implementatie van het Interinstitutioneel Akkoord. ${ }^{39}$

\section{Interactie met de instrumenten van de Commissie}

In het Interinstitutioneel Akkoord 2016 wordt nogmaals duidelijk gemaakt dat het Parlement en de Raad in hun werkzaamheden de impact assessments en evaluaties van de Commissie moeten gebruiken. ${ }^{40}$ Omdat er relatief weinig bekend is over de wijze waarop het Parlement en de Raad zich bezighouden met de impact assessments en evaluaties die de Commissie opstelt, volgt hierna een uiteenzetting wat de twee instellingen met deze instrumenten doen qua analyse en gebruik. $^{41}$

\subsection{Impact assessments en evaluaties in het Parlement}

Het Parlement heeft sinds de publicatie van het Niebler-rapport ${ }^{42}$ over het garanderen van onafhankelijke impact assessments stappen gezet om zich meer bezig te houden met wetgevingsbeleid. Zo werd eind 2013 de European Parliamentary Research Service (EPRS) opgericht als directoraat generaal (DG) in de administratie van het Parlement. Het doel was meer ondersteuning te bieden aan de parlementsleden voor het doen van onderzoek en analyses, en hierdoor ook meer capaciteit te genereren om de Commissie en andere instellingen te controleren. ${ }^{43}$ Een onderdeel van de EPRS, het directoraat Impact Assessments and European Added Value, houdt zich bezig met de wetgevingscyclus. ${ }^{44}$ In dit directoraat

Zie ST 10455 2019, p. 3 en ST 15109 2019, p. 3-4, waar in de documenten letterlijk dezelfde tekst over dit onderwerp opgeschreven staat.

40 PbEU 2016, L 123, p. 1-14, art. 12-24.

41 Deze vraag heb ik reeds opgeworpen in het 2016-artikel (Van Golen 2016, p. 308), maar tot heden is er bijna geen enkele publicatie gewijd aan hoe het Parlement en de Raad omgaan met impact assessments en evaluaties, terwijl toch zeker het Parlement grote stappen heeft gezet.

42 PbEU 2012, C 380E, p. 31-39.

43 EPRS, The work of EPRS, the first three years: 2014 to 2016, beschikbaar op europarl.europa.eu/ EPRS/The_work_of_EPRS-2014_to_2016.pdf, p. 4-5, bezocht op 26 september 2020.

44 Naast dit onderdeel bevat het EPRS nog het directoraat voor onderzoek voor MEP's, waarin voornamelijk politieke analyses en onderzoek uitgevoerd worden, en het directoraat voor de bibliotheek. 
houden verschillende units zich bezig met impact assessments (IMPA), ex post evaluaties (EVAL), het analyseren van EU Added Value (EAVA), het onderzoeken van mogelijke wetenschappelijke en technologische opties voor wetgeving (STOA), een Global Trends-unit (TREN) en de controle op de Raad en regeringsleiders (ECOS). ${ }^{45}$ Voor dit artikel zijn de units IMPA en EVAL relevant. ${ }^{46}$

\subsubsection{Impact assessments in het Parlement}

IMPA is de afgelopen zes jaar bezig geweest met het analyseren van de impact assessments van de Commissie. Dit doet de afdeling door het produceren van initial appraisals, korte overzichten van gemiddeld een pagina of 10 waarin de belangrijkste punten van de impact assessment worden behandeld. ${ }^{47}$ Daarnaast wordt aan de hand van de Better Regulation-documenten van de Commissie en het Impact Assessment Handbook ${ }^{48}$ van het Parlement een analyse gemaakt van de kwaliteit van de impact assessments. De kwaliteit van de impact assessments wordt beoordeeld op tien punten, waaronder de probleemanalyse, de analyse van de verschillende beleidsopties en de impact daarvan, de kwaliteit van dataverzameling en de samenhang tussen het voorstel en de impact assessment. De EPRS heeft onlangs een uitgebreide evaluatie gemaakt van alle initial appraisals om te kunnen analyseren welke sterke en zwakke punten de impact assessments hebben. ${ }^{49}$ Sterke punten waren de probleemdefinitie, de sectie over monitoring en evaluatie, en de samenhang tussen voorstel en de impact assessment. Minder goed beoordeeld waren de onderdelen presentatie van de verschillende beleidsopties en de impact daarvan, terwijl dit juist wezenlijke onderdelen zijn van de impact assessment. ${ }^{50}$ Dit komt overeen met hetgeen de RSB in haar jaarlijkse rapport uit 2018 aangaf met betrekking tot de zwakkere onderdelen van de impact assessment. ${ }^{51}$ In de marge doemt hier dan wel de vraag op waarom er een dubbele check op impact assessments gezet wordt. In principe beoordeelt de RSB al de kwaliteit van de impact assessments, maar IMPA doet enigszins hetzelfde nogmaals. ${ }^{52}$ Vanuit het oogpunt van samenvatting kan een initial appraisal wel een toegevoegde waarde zijn. Hoewel er in de Better Regulation Guidelines staat dat

EPRS, The work of EPRS, the first four years: 2014 to 2017, beschikbaar op europarl.europa.eu/ EPRS/EPRS-Four-year-report-2014-17_final_for_web.pdf, p. 29-34, bezocht op 26 september 2020.

46 Voor meer informatie over het EPRS, zie de website van het EPRS: epthinktank.eu, bezocht op 26 september 2020.

47 EPRS, Impact Assessment and European Added Value work during the eighth legislative term, 2014-2019, PE 631.753, p. 3, beschikbaar op europarl.europa.eu/RegData/etudes/BRIE/ 2019/631753/EPRS_BRI(2019)631753_EN.pdf, bezocht op 26 september 2020.

48 Beschikbaar op europarl.europa.eu/EPRS/impact_assesement_handbook_en.pdf, bezocht op 26 september 2020.

49 Zie hiervoor EPRS, Appraising the quality of the European Commission's impact assessments - Trends and developments from 2015 to 2018, beschikbaar op europarl.europa.eu/RegData/etudes/STUD/ 2019/642807/EPRS_STU(2019)642807_EN.pdf, bezocht op 26 september 2020.

50 Idem, p. II.

51 Regulatory Scrutiny Board, Annual report 2018, 2019, p. 12-14, beschikbaar op ec.europa.eu/info/ sites/info/files/rsb_report_2018_en.pdf, bezocht op 26 september 2020.

52 Een opmerking die ik tijdens interviews met Commissiemedewerkers vaker heb gehoord. 
een impact assessment van 30-40 pagina's hoofdtekst voldoende is, neigt de gemiddelde impact assessment al snel naar tientallen pagina's meer, exclusief annexen. ${ }^{53}$ Een andere redenering kan zijn dat vanuit het oogpunt van (democratische) controle van de verschillende instellingen het goed is om nog eens de kwaliteit te bestuderen van de impact assessments. Weliswaar controleert de RSB de kwaliteit al als het document nog intern in de Commissie wordt bewerkt, maar aangezien de RSB deels bevolkt wordt door Commissiemedewerkers zelf, is een onafhankelijke controle geen overbodige luxe. ${ }^{54}$

Naast de initial appraisals kan IMPA ook nog drie andere producten op verzoek van parlementsleden produceren: een gedetailleerde appraisal van een impact assessment waarbij vaak op een specifiek onderdeel de focus wordt gelegd, ${ }^{55}$ een vervangende of aanvullende impact assessment indien het Parlement van mening is dat de Commissie onvolledig is geweest in de impact assessment of geen impact assessment heeft geproduceerd, ${ }^{56}$ en als laatste een impact assessment op substantiële amendementen van het Parlement op een Commissievoorstel. ${ }^{57}$ Deze laatstgenoemde categorie vloeit voort uit de afspraken uit het oude Interinstitutioneel Akkoord, waarin opgenomen is dat het Parlement en de Raad zelf impact assessments zullen uitvoeren bij substantiële wijzigingen van de wetgevingsvoorstellen. ${ }^{58}$ Ook onder het huidige akkoord blijft dit een discretionaire bevoegdheid voor het Parlement en de Raad. ${ }^{59}$ Op dit moment zijn er slechts acht impact assessments van substantiële wijzigingen geproduceerd door de EPRS. Ten slotte heeft de EPRS een eigen (zogenoemde 'ad hoc') impact assess-

53 Better Regulation Guidelines, p. 30.

54 Met de veranderingen van het IAB naar het RSB werd ook de samenstelling veranderd. Op dit moment zitten er drie Commissiemedewerkers in, en twee externe leden die geen eerdere ervaring in de Commissie hebben gehad. Zie ec.europa.eu/info/law/law-making-process/regulatoryscrutiny-board/members-regulatory-scrutiny-board-0_en, bezocht op 26 september 2020.

55 Een recent voorbeeld is de detailed appraisal van het voorstel voor de bescherming van werknemers tegen carcinogenen en mutagenen. Omdat de initial appraisal te beperkt was, heeft de parlementaire commissie gevraagd om een detailed appraisal, zodat meer in detail gekeken kan worden naar het effect van specifieke stoffen. Deze is te vinden op europarl.europa.eu/RegData/ etudes/STUD/2018/627144/EPRS_STU(2018)627144_EN.pdf, bezocht op 26 september 2020.

56 Een voorbeeld: het EPRS heeft onlangs een vervangende impact assessment gemaakt voor wijzigingen in de regelgeving rondom het European Travel Information and Authorisation System (ETIAS). Bij de betrokken voorstellen had de Commissie geen impact assessment uitgevoerd.

57 EPRS, Impact Assessment and European Added Value work during the eighth legislative term, 2014-2019, p. 3-4.

58 PbEU 2003, C 321, p. 1-5, overweging 30.

$59 \mathrm{PbEU}$ 2016, L 123, p. 1-14, overweging 15. De Commissie heeft getracht om het maken van impact assessments verplicht te stellen in de conceptversie van het IIA dat zij hadden opgesteld. Zie hierover Van Golen 2016, p. 303. 
ment gemaakt voor de mogelijke invoering van een Europese wet voor bestuursprocesrecht. ${ }^{60}$

Hoewel IMPA een aanzienlijke hoeveelheid documenten heeft geproduceerd, ${ }^{61}$ is uiteraard de vraag van belang of deze documenten daadwerkelijk een bijdrage leveren aan de betrokkenheid van het Parlement bij het Better Regulation-proces. In het activiteitenrapport van 2018 schetst de EPRS dat het bezig is om meer 'awareness' te genereren voor hun werk binnen het Parlement. ${ }^{62}$ Een masterscriptie-onderzoek naar de zichtbaarheid van het gebruik van deze initial appraisals laat zien dat het daadwerkelijk zichtbare (voor externe onderzoekers) gebruik te wensen over laat. ${ }^{63}$

\subsubsection{Evaluaties in het Parlement}

Zoals IMPA van belang is voor het ex ante gedeelte van het wetgevingsproces, zo is de unit EVAL van belang voor de evaluatiekant van de cyclus. Allereerst produceert EVAL European implementation assessments (EIA's ${ }^{64}$ ) ter ondersteuning van implementatierapporten die het Parlement aanneemt. ${ }^{65}$ De implementation assessments volgen in grote lijnen de evaluatiecriteria uit de Better Regulation Guidelines en zijn gebaseerd op openbare data. ${ }^{66}$ Deze EIA's zijn een Parlementsversie van de evaluaties die door de Commissie geproduceerd worden. Volgens het

60 De impact assessment is beschikbaar op europarl.europa.eu/RegData/etudes/STUD/ 2018/621841/EPRS_STU(2018)621841_EN.pdf, bezocht op 26 september 2020, en volgt grotendeels hetzelfde stramien als de impact assessments van de Commissie. Voor meer informatie over een Europese Awb, zie A.C.M. Meuwese, 'Het Europees Parlement op de bres voor een Europese Awb', RegelMaat (28) 2013, afl. 2, p. 135-139, en meer recent een blog van dezelfde auteur op www.publiekrechtenpolitiek.nl/een-europese-awb-de-commissie-heeft-er-nog-steedsgeen-zin-in/, bezocht op 26 september 2020.

61 Aan het eind van 2019 heeft IMPA 248 initial appraisals, zes gedetailleerde appraisals, zes vervangende/aanvullende impact assessments en acht impact assessments van substantiële wijzigingen uitgebracht. Zie hiervoor EPRS, European Parliament work in the fields of Impact Assessment and European Added Value, activity report 2018. De periode in het rapport loopt van juli 2012 tot eind 2018. In 2019 zijn nog vier initial appraisals gemaakt en één vervangende impact assessment. Dit is simpelweg een optelsom van de documenten uit 2019 op europarl.europa.eu/ thinktank/en/search.html?policyAreas=EXIMAS, bezocht op 26 september 2020.

62 EPRS, European Parliament work in the fields of Impact Assessment and European Added Value, activity report for 2018, beschikbaar op europarl.europa.eu/EPRS/EPRS_631.723_IA-EAVActivity_Report_2018.pdf, bezocht op 26 september 2020.

63 M.Ş. Öztekin, Initial Appraisals in het Europese wetgevingsproces - Een verkennend onderzoek naar Initial Appraisals en het verband met een beter Europees wetgevingsproces (masterscriptie Rechtsgeleerdheid Tilburg University), 2019. Deze student werd begeleid door mijzelf, met prof. R.A.J. van Gestel als tweede lezer.

64 Niet te verwarren met Environmental Impact Assessments uit Richtlijn 2011/92/EU van het Europees Parlement en de Raad van 13 december 2011 betreffende de milieueffectbeoordeling van bepaalde openbare en particuliere projecten, $P b E U$ 2012, L 26, p. 1-21. EIA's onderzoeken hoe de implementatie van Europese regelgeving is verlopen en evalueren dit langs de vijf evaluatiecriteria die de Commissie ook gebruikt in haar evaluaties (effectiviteit, efficiëntie, coherentie, relevantie en EU-toegevoegde waarde).

65 EPRS, Impact Assessment and European Added Value work during the eighth legislative term, 2014-2019, EPRS 2019a, p. 8.

66 De vijf criteria zijn: effectiveness, efficiency, coherence, relevance en EU added value. Better Regulation Toolbox 2017, p. 10. 
rapport van de EPRS zelf zijn 47 van de 65 implementatierapporten die door het Parlement zijn aangenomen in de periode 2015-2019 ondersteund door een EIA, waarbij in 37 van de 47 gevallen ook een presentatie is gehouden bij het desbetreffende comité. ${ }^{67}$ Opvallend is dat het rapport over de activiteiten van EVAL vrij specifiek ingaat op het (zichtbare ${ }^{68}$ ) gebruik door het Parlement van de stukken, terwijl dat bij het gedeelte over IMPA en de initial appraisals lang niet zo uitgebreid gerapporteerd is. ${ }^{69}$

Naast de EIA's maakt EVAL ook implementation appraisals. ${ }^{70}$ Hierbij analyseert EVAL wetgeving die herzien dient te worden om alvast een beeld te krijgen van de implementatie van die wetgeving. ${ }^{71}$ Volgens het rapport van de EPRS is een deel van deze 91 appraisals niet alleen gebruikt door de desbetreffende comités, maar worden ze ook door bijvoorbeeld nationale parlementen gebruikt om de voorstellen van de Commissie te analyseren. ${ }^{72}$ Hiervan worden geen voorbeelden gegeven.

Ook houdt EVAL een aantal lijsten bij onder de noemer Rolling Check-List. Zo zijn er lijsten voor de resultaten van de onderzoeken van de Europese Rekenkamer, ${ }^{73}$ evaluatieclausules in internationale overeenkomsten, ${ }^{74}$ evaluatieclausules in EUwetgeving ${ }^{75}$ en de geplande en voltooide evaluaties van de Commissie. ${ }^{76}$ Op deze manier probeert EVAL, en dus het Parlement, meer grip te krijgen op de ex post kant van EU-wetgeving door een beter beeld te krijgen van wat er allemaal geëvalueerd wordt of had moeten zijn op welk moment. ${ }^{77}$

68 Het rapport stelt dat de zichtbaarheid zelfs enorm hoog is doordat in de resoluties die het Parlement aanneemt in een van de overwegingen een referentie naar de EIA van EVAL wordt opgenomen. Een voorbeeld: PbEU 2017, C 355, p. 17 bevat de overweging 'having regard to the European Parliamentary Research Service study of February 2015 entitled "Implementation of the European Citizens' Initiative"'.

69 EPRS 2019a, vergelijk p. 3 met p. 8-9.

70 EPRS, Evaluation and ex-post impact assessment at EU level, 2016, p. 7, beschikbaar op europarl.europa.eu/RegData/etudes/BRIE/2016/581415/EPRS_BRI(2016)581415_EN.pdf, bezocht op 26 september 2020.

71 EPRS 2019a, p. 11-12.

72 EPRS 2019a, p. 12.

73 EPRS, Special Reports of the European Court of Auditors - A Rolling Check-list of recent findings, 2019b, beschikbaar op europarl.europa.eu/RegData/etudes/STUD/2019/631735/EPRS_STU (2019)631735_EN.pdf, bezocht op 26 september 2020.

74 EPRS, International Agreements - Review and Monitoring Clauses A Rolling Check-List, 2019c, beschikbaar op europarl.europa.eu/RegData/etudes/STUD/2019/631768/EPRS_STU(2019)631 768_EN.pdf, bezocht op 26 september 2020.

75 EPRS, Review Clauses in EU Legislation - A Rolling Check-List, 2018, beschikbaar op europarl.europa.eu/RegData/etudes/STUD/2018/621821/EPRS_STU(2018)621821_EN.pdf, bezocht op 26 september 2020.

76 EPRS, Evaluation in the European Commission - Rolling Check-List and State of Play, 2017, beschikbaar op europarl.europa.eu/RegData/etudes/STUD/2020/654170/EPRS_STU(2020)654170_ EN.pdf, bezocht op 26 september 2020.

77 De laatste uitgave van deze checklist zoals genoemd in de vorige voetnoot is zeker lezenswaardig, aangezien hier ook de stand van de literatuur over dit onderwerp wordt doorgenomen. 


\subsection{Impact assessments en evaluaties in de Raad}

Op het eerste gezicht lijkt het alsof de Raad zich weinig bekommert om de Better Regulation Agenda van de Commissie. De Raad heeft tenslotte geen zelfstandige impact assessments of evaluaties uitgevoerd, noch heeft hij een dienst die overeenkomsten vertoont met de EPRS van het Parlement. Niettemin is er sinds het oude Interinstitutioneel Akkoord uit 2003 ook bij de Raad enige activiteit geweest op het gebied van wetgevingsbeleid. Zo is er na het sluiten van de Common Approach on Impact Assessments ${ }^{78}$ door de Raad een document rondgestuurd over hoe werkgroepen en comités van de Raad om kunnen gaan met impact assessments tijdens hun werkzaamheden. ${ }^{79}$ Tevens is er in de Raadsdocumenten terug te vinden dat de Raad zich committeert aan het uitvoeren van impact assessments op substantiële wijzigingen door de Raad. ${ }^{80}$ Dat commitment lijkt niet erg van de grond te komen, omdat al in 2013 al valt te lezen dat (a) er op verschillende wijze wordt omgegaan met het gebruik van impact assessments binnen Raadswerkgroepen, en (b) de Raad niet erg geneigd is om zelf impact assessments te produceren voor substantiële amendementen. ${ }^{81}$ De reden voor het gebrek aan eigen impact assessments is het feit dat geen overeenstemming bestaat over wat nu een substantieel amendement is, en dat de Raad simpelweg de capaciteit niet heeft om een eigen impact assessment unit op te richten, die ook nog eens alle lidstaten hierbij kan betrekken. ${ }^{82}$ Om het probleem onder a aan te pakken wordt een checklist opgesteld, zodat de werkgroepen hiervan gebruik kunnen maken tijdens de bespreking van de impact assessment. Deze aanpak lijkt volgens de evaluaties van de Raad zijn vruchten af te werpen. ${ }^{83}$ Ook begint langzamerhand in de jaarlijkse evaluatie van het gebruik van impact assessments in de Raad enig commentaar op de kwaliteit van de impact assessments te ontstaan. Zo valt te lezen in het rapport over 2016 dat lidstaatdelegaties kritiek hadden op de data, de beleidskeuzes en het (niet) bespreken van bepaalde impacts. ${ }^{84}$ Daarnaast constateert de Raad dat het gebrek aan impact assessment gebruikt wordt door lidstaten om terughoudend te zijn over voorstellen. ${ }^{85}$ In latere jaarverslagen wordt zelfs algemene kritiek geuit op het gebrek aan impact assessments nu dit in 43 van de 101 gevallen voorkwam. ${ }^{86}$ In sommige van deze verslagen wordt ook verwezen naar het Interinstitutioneel Akkoord 2016, waarin staat dat de Commissie zich heeft voorgenomen om voor voorstellen en andere maatregelen met

78 Een voortvloeisel uit de afspraken uit het IIA 2003, de Common Approach on Impact Assessments, zijn afspraken over hoe de drie instellingen omgaan met impact assessments. Een aantal van die afspraken is uiteindelijk ook weer beland in het IIA uit 2016. Zie ST 149012005 INIT.

79 ST 93822006 INIT.

80 Zie ST 169762011 INIT, p. 4.

81 ST 84062013 INIT, p. 4.

82 ST 84062013 INIT, p. 10, en nogmaals besproken in ST 97862016 INIT in het licht van de nieuwe Better Regulation Agenda.

83 Zie 108822014 INIT, p. 4-5, 8749 2015, p. 9, en meer ambivalent ST 97862016 INIT, p. 5.

84 ST 97862016 INIT, p. 6, en herhaald in ST 98652017 REV 1, p. 7.

85 ST 97862016 INIT, p. 4. Zie over het gebrek van impact assessments in 2018 bij wetgevingsvoorstellen in het algemeen impactassessmentinstitute.org/absence-of-ia-j-o-18, bezocht op 26 september 2020.

86 ST 100142019 INIT, p. 13. 
een significante impact wel degelijk een impact assessment uit te voeren. ${ }^{87}$ Verder komt het voor dat de Raad om aanvullende informatie vraagt indien hij het idee heeft dat dit ontbreekt in de impact assessment. ${ }^{88}$ Dit komt ook doordat de Raad geen formele procedure heeft om de Commissie te verzoeken een impact assessment voor te bereiden. ${ }^{89}$ Dat een verzoek om een impact assessment toch gedaan kan worden, blijkt wel uit een latere conclusie van de Raad, waarin hij oproept tot het uitvoeren van een impact assessment met betrekking tot het vergroten van de reikwijdte van de Passenger Name Records-richtlijn. ${ }^{90}$

Hoewel de Raad het oprichten van een eigen dienst voor het uitvoeren van impact assessments voor langere tijd niet haalbaar achtte, is in 2017 toch besloten om een pilot op te zetten voor het uitbesteden van de capaciteit om een impact assessment te maken op substantiële amendementen. ${ }^{91}$ Deze pilot wordt wel beperkt gehouden, doordat er eisen verbonden zijn aan de aanvraag van een impact assessment: (a) het moet gaan om een substantieel amendement, (b) er moet genoeg steun van de lidstaten zijn voor het amendement, en (c) het moet het werk van de Raad niet onnodig vertragen. ${ }^{92} \mathrm{Nu}$ wordt niet geheel duidelijk wanneer er sprake is van 'onnodige' vertraging. In het enige geval tot nu toe is er sprake van onnodige vertraging omdat er bijna een einde komt aan de institutionele en wetgevingscyclus en door een impact assessment aan te vragen dit traject niet afgerond zou kunnen worden. ${ }^{93}$

Wat betreft ex post evaluaties is er weinig informatie beschikbaar over de rol die de Raad hier precies in speelt. In het rapport van de Europese Rekenkamer wordt in punten 69-70 wel verwezen naar de rol van 'ex post reviews' in de werkgroepen van de Raad, maar volgens het onderzoek wordt dit soort ex post evaluaties weinig geagendeerd. ${ }^{94}$ Zoals de Rekenkamer zelf al nuanceert en de Raad in zijn respons op het rapport ook zegt: dat zij niet geagendeerd worden, betekent niet dat de evaluaties niet besproken en/of gebruikt worden. ${ }^{95}$

\section{De verandering in de Regulatory Scrutiny Board}

Naast de veranderingen die de medewetgevers hebben doorgevoerd sinds het begin van 2016, is ook een aantal zaken bij de Commissie zelf gewijzigd. De meest in het oog springende verandering was het omvormen van de oude Impact Assess-

ST 100142019 INIT, p. 13.

ST 97862016 INIT, p. 6 en ST 98652017 REV 1, p. 7.

ST 100142019 INIT, p. 14.

ST 126492019 REV 1.

ST 52492017 INIT, p. 3.

ST 76192017 INIT, p. 2 en ST 86802017 INIT, p. 3.

ST 100142019 INIT, p. 18-19. Overigens werd het verzoek ook afgewezen omdat het niet zou voldoen aan het eerste vereiste van een substantiële wijziging.

European Court of Auditors, Ex-post review of EU legislation: a well-established system, but incomplete, Luxemburg: EU Publications Office 2018, p. 30. Beschikbaar op eca.europa.eu/Lists/ ECADocuments/SR18_16/SR_BETTER_REGULATION_EN.pdf, bezocht op 26 september 2020.

Zie voor de reactie van de Raad in het rapport p. 65-66. 
Cijfers 2014-2019 uit de jaarlijkse RSB-rapporten uit 2017-2020. Het rapport van de RSB over 2019 toont een vrij afwijkend aantal van 1 impact assessment. Onduidelijk is waar dit verschil vandaan komt.

\begin{tabular}{|c|c|c|c|c|c|c|c|}
\hline \multicolumn{3}{|c|}{ Impact assessments (IA's) } & \multicolumn{4}{|c|}{ Evaluaties (EV's) } & \multirow[b]{2}{*}{ Percentage } \\
\hline Jaar & $\begin{array}{l}\text { Aantal } \\
\text { IA's }\end{array}$ & Negatief & Percentage & Jaar & $\begin{array}{l}\text { Aantal } \\
\text { EV's }\end{array}$ & Negatief & \\
\hline 2014 & 25 & 10 & $40 \%$ & 2014 & n.v.t. & n.v.t. & n.v.t. \\
\hline 2015 & 29 & 14 & $48 \%$ & 2014 & n.v.t. & n.v.t. & n.v.t. \\
\hline 2016 & 60 & 25 & $42 \%$ & 2016 & 7 & n.v.t. & n.v.t. \\
\hline 2017 & 53 & 23 & $43 \%$ & 2017 & 17 & 7 & $41 \%$ \\
\hline 2018 & 76 & 21 & $28 \%$ & 2018 & II & 3 & $27 \%$ \\
\hline 2019 & 16 & 5 & $31 \%$ & 2019 & 17 & 8 & $47 \%$ \\
\hline
\end{tabular}

ment Board (IAB) tot de nieuwe RSB. ${ }^{96}$ De grootste wijziging in de taken van de RSB zou zijn dat zij naast de kwaliteit van impact assessments ook de kwaliteit van evaluaties zou gaan beoordelen. ${ }^{97}$ Gezien de cyclus die de Commissie in haar beleidsdocumenten promoot, is dit een logische stap. Minder logisch is dat de RSB wel alle impact assessments en fitness checks controleert, maar wat betreft evaluaties een keuze maakt. ${ }^{98}$

In de jaarlijkse rapporten ${ }^{99}$ beschrijft de RSB haar werkzaamheden wat betreft het controleren van de kwaliteit van impact assessments en evaluaties. Allereerst in tabel 1 een kort overzicht van de getallen wat betreft het aantal behandelde impact assessments en de negatieve beoordeling daarvan.

Bij een negatief oordeel dient de desbetreffende impact assessment of evaluatie opnieuw ingediend te worden bij de RSB. Hierin zit wel een verschil: bij een negatieve opinie moet de impact assessment na aanpassing terug naar de RSB voordat het proces verder kan; bij evaluaties mag een aangepast rapport voorgelegd worden, maar kan het proces wel verder gaan. ${ }^{100}$ Sinds 2018 is een daling te zien in de hoeveelheid impact assessments die een negatief onderdeel hebben gekre-

96 Van Golen 2016, p. 298.

97 De kwaliteit gaat zowel over de inhoud als over de procedures. Bij beide documenten zijn dezelfde vijf criteria (effectiviteit, efficiëntie, coherentie, relevantie en EU-toegevoegde waarde) van belang.

98 De RSB zal voornamelijk 'major' evaluaties beoordelen: evaluaties vanwege een REFIT-evaluatie (specifieke evaluaties die controleren of de wetgeving nog wel functioneert), evaluaties die verbonden zijn aan het Meerjarig Financieel Kader en verder evaluaties die zij nog belangrijk acht, gebaseerd op de plannen van de verschillende DG's. Zie SWD(2015)0111, p. 9, de Better Regulation Toolbox, p. 12 en de Rules of Procedure van de RSB, art. 7 lid 2. De Rules of Procedure zijn te vinden via ec.europa.eu/info/sites/info/files/rsb_rules_of_procedures_-_revision_2020_en.pdf, bezocht op 26 september 2020.

99 Te vinden op ec.europa.eu/info/law/law-making-process/regulatory-scrutiny-board_en, bezocht op 26 september 2020.

100 Zie Tool \#3 in de Better Regulation Toolbox, p. 14-15. 
gen. Dit kan betekenen dat de invloed van de RSB merkbaar is in de kwaliteit van de impact assessments die gemaakt worden. Dit is ook de tendens in de jaarlijkse rapporten van de $\mathrm{RSB}$, waarin besproken wordt wat de sterke en zwakke punten van de impact assessments zijn en hoe de opinie van de RSB de kwaliteit van het rapport heeft veranderd. Overigens valt wel op dat ook in het laatste rapport uit 2018 blijkt dat een merendeel van de elementen van de impact assessments maar ternauwernood een 'acceptabel' scoort in de eerste ronde. ${ }^{101}$ Ook moet de RSB constateren dat haar oordeel van 'positive with reservations', wat het midden houdt tussen positief en negatief, tot twee keer zo weinig aanpassingen leidt dan een negatief oordeel. ${ }^{102}$ Dit is niet geheel onverwacht, zeker aangezien het vermoedelijk mogelijk is om bij een negatief oordeel nog snel grote stappen voorwaarts in kwaliteit te kunnen maken. ${ }^{103}$ De RSB moet zelfs concluderen dat de uiteindelijke kwaliteit, gemeten aan het eind van het proces van impact assessments, niet heeft geleid tot een verbetering in kwaliteit als men kijkt naar 2017 en 2018. ${ }^{104}$ Omdat er in 2019 weinig impact assessments zijn verschenen, heeft de RSB weinig aandacht aan de kwaliteit hiervan besteed in haar rapport over 2019. 105 Omdat 2019 een afrondjaar voor de Commissie-Juncker was, waarbij er (a) weinig impact assessments gepubliceerd zijn en (b) de impact assessments snel opgesteld moesten worden om te voldoen aan bepaalde beloftes die de Commissie had gemaakt met betrekking tot wetgeving, acht ik een toename in kwaliteit vrij klein. ${ }^{106}$

De RSB heeft 41 evaluaties met opmerkingen gepubliceerd op haar website. ${ }^{107} \mathrm{Op}$ grond van de meetings en de jaarrapporten van de RSB die ook terug te lezen zijn, heeft zij inmiddels wel meer evaluaties beoordeeld. ${ }^{108}$ Publicatie op de website

101 RSB 2019, p. 12. Alleen de presentatie gaat verder dan acceptabel. De rest zit op die grens of eronder. Geen enkel element komt in de buurt van de kwalificatie 'goed'. De jaarlijkse rapporten van de RSB zijn beschikbaar op ec.europa.eu/info/law/law-making-process/regulatory-scrutinyboard_en, bezocht op 26 september 2020.

102 RSB 2019, p. 13-14.

103 Voorstelbaar is dat het lastig is om naderhand nog nieuw onderzoek te genereren of een slechte methodologie aan te passen, iets wat ook in de rapporten van de RSB staat.

104 RSB 2019, p. 32. De kwaliteit komt dus net boven 'acceptabel' uit en is nog lang niet bij 'goed'.

105 Volgens het rapport is er maar 1 impact assessment in 2019 gepubliceerd. Op de speciale website voor de documenten van de RSB zijn er echter meer beoordelingen te vinden. Zie ec.europa.eu/ transparency/regdoc/?fuseaction=ia, bezocht op 26 september 2020.

106 Ook heeft de Commissie bijna geen wetgevende voorstellen opgenomen in haar werkprogramma van 2019. Zie eur-lex.europa.eu/resource.html?uri=cellar\%3Ada6e3b4b-d79b-11e8-90c0-01aa 75ed71a1.0013.02/DOC_2\&format=PDF, p. 1-2, bezocht op 26 september 2020.

107 Beschikbaar op ec.europa.eu/info/regulatory-scrutiny-board-opinions-evaluations-and-fitnesschecks_en, bezocht op 26 september 2020. De fitness check voor de monitoring en reporting obligations in het EU-milieurecht staat twee keer op die website.

108 De meetings zijn terug te vinden op ec.europa.eu/info/publications/meetings-regulatoryscrutiny-board_en, bezocht op 26 september 2020, en de jaarrapporten staan op de algemene pagina van de RSB (ec.europa.eu/info/law/law-making-process/regulatory-scrutiny-board_en, bezocht op 26 september 2020) onder de kop 'Annual Reports'. De drie rapporten bij elkaar opgeteld kom ik tot 38 evaluaties die de RSB tussen 2016 en 2018 heeft gezien. In het jaarrapport van de RSB komt zij zelf tot het aantal van 35. Deze discrepantie komt vermoedelijk doordat een aantal evaluaties nog niet klaar was ten tijde van het 2018-rapport (het 2019-rapport is nog niet geschreven). 
volgt pas als de evaluatie als Commissiedocument gepubliceerd kan worden. Vermoedelijk hebben sommige evaluaties een negatief advies gekregen en wordt er nu dus nog verder aan gewerkt, waardoor publicatie nog niet kan volgen. Daarnaast is de RSB helaas niet altijd even grondig in de publicatie van afgeronde evaluaties op de website. ${ }^{109}$ Overigens is er ook een groot aantal evaluaties gepubliceerd als onderdeel van de impact assessment. ${ }^{110}$

Van de 52 evaluaties waren er 26 wetgevingsevaluaties en 26 programmaevaluaties. Van de 45 evaluaties waaraan een positief of negatief dictum is gegeven, ${ }^{111}$ kregen 18 evaluaties een eerste keer een negatieve beoordeling ( 7 over wetgeving, 11 over programmaevaluaties). In die gevallen die door de RSB negatief beoordeeld werden, waren de twee grootste factoren onduidelijkheid over de scope van de evaluatie (te breed, niet breed genoeg of vooral onduidelijk waarom specifieke wetgeving wel/niet is meegenomen) en de geleerde lessen van de evaluatie die als input kunnen dienen voor beleidsmakers. Dit waren ook de grootste probleempunten voor evaluaties met een eerste positieve beoordeling, met als derde grote factor de effectiviteit en efficiëntie van de wetgeving/het programma en de manier waarop daarover gerapporteerd werd. ${ }^{112}$ In de jaarrapporten van de RSB is de samenhang van de evaluatie het grootste probleempunt, op de voet gevolgd door presentatie en de relevantie/EU-toegevoegde waarde. ${ }^{113}$ Net als bij impact assessments het geval was, ziet de RSB wel verbetering na een eerste negatieve opinie, maar blijft de kwaliteit van de evaluaties ook hangen rond de kwalificatie 'acceptabel'. ${ }^{114}$ Overigens wordt uit de jaarrapporten niet duidelijk wanneer een document de kwalificatie 'goed' zou bereiken. In het jaarrapport over 2019 wordt aangegeven dat een heel klein percentage het label 'goed' heeft ontvangen, maar waardoor dat komt of welke rapporten dat zijn is niet weergegeven. ${ }^{115}$

109 De eerste vijf evaluaties en de opinies werden in januari 2017 gepubliceerd. Vervolgens bleef het lang stil. Na een gesprek met een RSB-medewerker in juni 2017, waarin ik opmerkte dat er maar vijf evaluaties te vinden waren op de website, werden er prompt de volgende dag enkele evaluaties geplaatst. Gezien de plaatsingsmaanden wordt er vooral een aantal keer per jaar een verzamelde hoeveelheid online geplaatst (bijv. de bulk in december 2018 van evaluaties die door het jaar heen of zelfs het jaar daarvoor al waren besproken, evenals de bulk in april 2020). Ook is een tweetal evaluaties die volgens het jaarrapport uit 2016 van de RSB door haar zijn bekeken niet online te vinden op de RSB-website, maar wel al gepubliceerd (de Occupational Safety and Health Directive evaluatie (SWD(2017)0010) en de EMAS/Ecolabel evaluatie (SWD(2017)0253)).

110 De RSB kan, als de tijdnood groot is, een zogenoemde back-to-back evaluatie en impact assessment beoordelen. Hierbij worden de twee instrumenten dan deels parallel aan elkaar uitgevoerd in plaats van sequentieel. Zie hiervoor de Better Regulation Toolbox, Tool \#52 en RSB 2019, p. 37.

111 Zeven evaluaties waren beoordeeld voordat de RSB begin 2017 een positief/negatief oordeel introduceerde. Zie hierover ook het Annual report 2016 van de RSB, beschikbaar op ec.europa.eu/info/sites/info/files/2016-rsb-report_en.pdf, bezocht op 26 september 2020 .

112 Op basis van een zelfgemaakte analyse van de punten die de RSB noemt in de opinies van de evaluaties.

113 RSB 2019, p. 37.

114 RSB 2019, p. 39. Met als toevoeging op p. 38 dat de kwaliteit van impact assessments wel hoger ligt dan die van evaluaties.

115 RSB 2019, p. 21. 
Op basis van de rapporten van de RSB is er dus wel een langzame trend omhoog te zien in de kwaliteit van impact assessments en evaluaties. Niettemin geeft ook de RSB aan dat er nog een lange weg te gaan is, zeker wat betreft de kwaliteit van evaluaties. Voornaamste probleem is hierbij dat de controle van de RSB te laat in het proces komt. Logischerwijs is het lastig om als de evaluatie reeds is uitgevoerd, nog veranderingen aan te brengen in het ontwerp en de methodologie van het onderzoek dat wordt uitgevoerd. ${ }^{116}$ Hierdoor is de RSB upstream meetings gaan uitvoeren, waarbij de verschillende DG's voorafgaand aan het starten van een evaluatie al kunnen overleggen met de RSB en hier waardevolle input kunnen ophalen voor het opzetten van de evaluatie. ${ }^{117}$ Daarnaast geeft de RSB aan dat het van groot belang is voor de kwaliteit van de evaluaties dat voorafgaand een impact assessment is gemaakt waarin al aandacht is besteed aan de wijze waarop gegevens verzameld gaan worden teneinde goed te kunnen evalueren. ${ }^{118}$ Deze waarneming sluit goed aan bij het idee van de cyclus die elk wetgevingstraject doorloopt in de EU, waarvan impact assessment en evaluatie een belangrijk onderdeel zijn. Bovendien sluit dit goed aan bij het Evaluate First-beginsel, waarin verwacht wordt dat er eerst geëvalueerd wordt alvorens een nieuwe impact assessment te maken.

\subsection{Evaluate First-beginsel}

Het Evaluate First-beginsel werd al benoemd in de beleidsdocumenten uit 2010, toen nog Smart Regulation geheten, maar wordt eigenlijk pas met het verschijnen van de Better Regulation Guidelines serieus genomen. ${ }^{119}$ Het beginsel houdt in dat voordat men overgaat tot aanpassing (of überhaupt het proces begint dat leidt tot bijvoorbeeld een impact assessment) er eerst een evaluatie of fitness check gedaan moet zijn. ${ }^{120}$ De RSB heeft in haar jaarrapporten ook aandacht besteedt aan de mate waarin dit beginsel daadwerkelijk gehandhaafd is. Tabel 2 geeft een aantal aantallen hieromtrent weer.

Het jaar 2019 laat weer een dip zien in de hoeveelheid impact assessments die voldoen aan het beginsel, maar dit kan ook een uitschieter zijn. Dit kan komen doordat er meer gedelegeerde wetgeving gepubliceerd werd dan verordeningen en richtlijnen zelf. Hierbij kan men zich voorstellen dat het vasthouden aan het beginsel minder van belang is bij gedelegeerde wetgeving, nu de wijzigingen hierin minder ingrijpend zullen zijn dan bij het herzien van een richtlijn of een nieuwe verordening. ${ }^{121}$

119 Zie Europese Commissie 2010, p. 5. Volgens een medewerker van de RSB komt dat doordat pas vanaf 2015 door het Secretariaat-Generaal van de Commissie echt 'gehandhaafd' wordt hierop.

120 Zie ook Tool \#43 BRT, p. 317.

121 Overigens heeft een aantal van deze Commissieverordeningen wel degelijk gebruikgemaakt van de evaluatie van de kaderwetgeving waaronder zij vallen (in de meeste gevallen de Ecolabellingrichtlijn). 
Tabel 2

Cijfers 2016-2018 uit de jaarlijkse RSB-rapporten uit 2016, 2017 en 2018. Cijfers uit 2019 op basis van de opgetelde gepubliceerde impact assessments en evaluaties. In het jaarlijkse rapport van de Commissie is er 1 impact assessment voor een wijziging waarbij deze ook voldaan heeft aan het Evaluate First-beginsel.

\begin{tabular}{llll}
\hline $\begin{array}{l}\text { Evaluate First gehandhaafd in impact assessments voor wijzigingswetgeving } \\
\text { Jaar }\end{array}$ & $\begin{array}{l}\text { Totaal IA's } \\
\text { wijziging }\end{array}$ & $\begin{array}{l}\text { Totaal met evalua- } \\
\text { tie }\end{array}$ & Percentage \\
\hline 2016 & 44 & 22 & $50 \%$ \\
2017 & 40 & 30 & $75 \%$ \\
2018 & 55 & 40 & $78 \%$ \\
2019 & 14 & 8 & $57 \%$ \\
\hline
\end{tabular}

Duidelijk is dat de cijfers niet een consistente en volledige handhaving van het Evaluate First-beginsel laten zien. ${ }^{122}$ Daarnaast is het de vraag wanneer er sprake is van daadwerkelijk gebruik van de evaluatie. In $65 \%$ van de gevallen wordt er in een impact assessment verwezen naar een evaluatie. ${ }^{123}$ Deze verwijzing leverde meerdere soorten gebruik op: soms werd de evaluatie als bron gebruikt ter ondersteuning van de tekst, soms volgde de probleemdefinitie expliciet uit de resultaten van de evaluatie, en soms werden in de impact assessments bepaalde aanbevelingen getoetst uit de evaluatie. ${ }^{124}$ Ook is er een stijgende lijn te zien als men de jaren vóór 2015 (46,5\% van de wetgevingstrajecten werd geëvalueerd) vergelijkt met 2015-2018 (58\% geëvalueerd). Ook de mate waarin een evaluatie daadwerkelijk op tijd aangeleverd werd, ging omhoog van $20 \%$ naar $36 \% .{ }^{125}$ Dat lijkt erop te wijzen dat op papier het Evaluate First-beginsel werkt.

Niettemin moet er meteen een belangrijke nuance aangebracht worden op de cijfers van de RSB uit tabel 2. Weliswaar heeft driekwart van de impact assessments voor amenderende wetgeving procedureel gezien voldaan aan het beginsel (er is een evaluatie voorafgegaan), inhoudelijk gebruik is een ander verhaal. De RSB splitst de cijfers over 'evaluate first respected' netjes uit in haar jaarrapport, waardoor men de in tabel 3 weergegeven cijfers krijgt.

Tabel 3 laat een aanzienlijk lagere score zien voor het gebruik van de evaluaties. Wat de criteria voor het wel of niet gebruiken zijn, dan wel wanneer een evaluatie de kwalificatie 'inadequaat' krijgt, is niet duidelijk. Ook is niet duidelijk of de

122 Dit concludeerde ik reeds in Van Golen 2016, p. 306-307.

123 T. van Golen \& S. van Voorst, 'Towards a regulatory cycle: The use of evaluative information in impact assessments and ex-post evaluations in the European Union, European Journal of Risk Regulation (7) 2016, afl. 2, p. 398.

124 Van Golen \& Van Voorst 2016, p. 398. In mijn proefschrift heb ik deze inhoudelijke analyse niet uitgevoerd op de wetgevingstrajecten, maar heb ik alleen gekeken of er een evaluatie (tijdig) beschikbaar was.

125 Op tijd aangeleverd betekende in mijn proefschrift dat de evaluatie verscheen minstens een jaar voordat de impact assessment gepubliceerd werd. Zie hierover Van Golen \& Van Voorst 2016, p. 395. 
Tabel 3

Cijfers 2017-2018 uit de jaarlijkse RSB-rapporten uit 2018 en 2019.

Cijfers 2016 op basis van mijn proefschrift. Het jaarlijkse rapport over 2019 geeft aan dat er maar 1 impact assessment met evaluatie is, die, zover duidelijk, voldoet aan het gebruik.

\begin{tabular}{llllll}
\hline Handhaving van Evaluate First uitgesplitst over soort gebruik \\
Jaar & $\begin{array}{l}\text { Totaal } \\
\text { met } \\
\text { evalua- } \\
\text { tie }\end{array}$ & $\begin{array}{l}\text { Inadequate } \\
\text { kwaliteit eva- }\end{array}$ & $\begin{array}{l}\text { Evaluatie niet } \\
\text { (goed) gebruikt }\end{array}$ & $\begin{array}{l}\text { Evaluatie goed } \\
\text { gebruikt }\end{array}$ & $\begin{array}{l}\text { Percentage } \\
\text { goed gebruikte } \\
\text { evaluaties t.o.v. } \\
\text { totaal met eva- } \\
\text { luatie }\end{array}$ \\
\hline 2016 & 22 & n.v.t. & n.v.t. & n.v.t. & n.v.t. \\
2017 & 39 & 10 & 6 & 14 & $36 \%$ \\
2018 & 40 & 14 & II & 15 & $37,5 \%$ \\
2019 & 8 & n.v.t. & n.v.t. & n.v.t. & n.v.t. \\
\hline
\end{tabular}

inadequate evaluaties alsnog gebruikt zijn en in hoeverre dat de score voor de impact assessment beïnvloedt. De vraag is dan ook of Evaluate First slechts een procedureel vereiste is (er moet een evaluatie zijn gedaan, maar hoe deze is gebruikt is niet van belang) of ook een inhoudelijk vereiste. Deze nuancering doet de score met de kwalificatie 'goed' (driekwart van de amenderende wetgeving wordt gesteund door een evaluatie) wel enigszins teniet. Dat laat zien dat de koppeling tussen de evaluatie en impact assessment toch lastiger in elkaar zit. Niettemin is het positief om te zien dat er in de jaarlijkse rapporten, en dus ook de werkzaamheden van de RSB, steeds meer aandacht komt voor de koppeling tussen de twee instrumenten. In het laatste rapport uit 2018 bijvoorbeeld besteedt de RSB expliciet aandacht aan de versterkende rol van wetsevaluaties voor de daaropvolgende impact assessment. ${ }^{126}$

\section{De Europese Commissie en het wetgevingsbeleid}

In april 2019 publiceerde de Commissie haar resultaten van een stocktaking exercise, een inventaris van de vooruitgang die geboekt is met wetgevingsbeleid sinds de publicatie van de Better Regulation Agenda in 2015. De oefening, die eigenlijk een verkapte evaluatie is geweest van het wetgevingsbeleid van de afgelopen vier jaren, ${ }^{127}$ is samengevat in een mededeling, ${ }^{128}$ maar bevat ook een uitgebreidere bijlage $^{129}$ en een literatuurstudie. ${ }^{130}$ De mededeling bespreekt het geheel langs vier lijnen: het openen van de beleidscyclus, de gebruikte instrumenten, het fit-

126 RSB 2019, p. 37-41.

127 Meerdere Commissiemedewerkers wezen er met een knipoog tijdens mijn interviews op dat het typisch was dat het geen evaluatie mocht heten, vermoedelijk omdat de Commissie daarmee aan de (zware) eisen en procedures uit hun eigen beleidsdocumenten zou moeten voldoen.

$128 \operatorname{COM}(2019) 0178$.

$129 \operatorname{SWD}(2019) 0156$.

130 G. Listorti e.a., The debate on the EU Better Regulation Agenda: a literature review, Luxemburg: EUR, Publications Office of the European Union 2019, doi:10. 2760/46617, JRC116035. 
for-purpose houden van wetgeving, en het wetgevingsbeleid als gedeelde taak. Daarnaast bevat de bijlage een veelheid aan informatie over de verschillende methoden die de Commissie heeft gebruikt om het onderzoek voor dit rapport uit te voeren. Informatie voor het rapport komt van een publieke consultatieronde, van gerichte consultatie door Commissiemedewerkers, overige Commissie-onderdelen die feedback geven (RSB, REFIT-platform ${ }^{131}$ ), alsmede interviews met medewerkers van andere instellingen (de Raad, het Comité van de Regio's, het Europees Economisch en Sociaal Comité, het Europees Parlement) en van rapporten (de OECD Regulatory Policy Outlook $2018^{132}$ diende als input, evenals het al eerdergenoemde rapport van de Europese Rekenkamer). Ook bevat de literatuurstudie een veelheid aan materiaal over wat er de afgelopen jaren gepubliceerd is aan onderzoek op dit terrein. ${ }^{133}$ Een belangrijk punt uit het rapport dat ook in mijn proefschrift naar voren komt, is dat de timing van evaluaties een grote hindernis voor de wetgevingscyclus kan vormen. ${ }^{134}$ Dit kan meerdere redenen hebben. Zo is er altijd discussie over hoeveel jaar na inwerkingtreding van wetgeving er een mogelijkheid is tot evalueren. In de EU levert dat een extra probleem op bij implementatie van richtlijnen. Niet elk land zal op hetzelfde moment de implementatie af hebben, deadlines of niet. Dan zou het kunnen dat pas EUbreed kan worden geëvalueerd nadat het laatste land de implementatie afrondt en er vervolgens nog een aantal jaar moet worden gewacht voordat de effecten van de richtlijn zich manifesteren. ${ }^{135}$ Dan is het maar de vraag of de timing van de evaluatie wel uitkomt met het werkprogramma en het starten van een wijzigingstraject voor wetgeving die wellicht vanwege andere redenen (technologische ontwikkeling bijvoorbeeld) aangepast moet worden. Het rapport gaat hier niet verder op in.

Aan het eind van deze uitgebreide stocktaking exercise is echter geen duidelijke conclusie te vinden over vervolgstappen die genomen moeten worden. ${ }^{136}$ Ook in de bijlage blijven de conclusies aan de oppervlakte, terwijl het rapport ${ }^{137}$ over subsidiariteit en proportionaliteit wel duidelijke intentieverklaringen bevat van de Commissie. De werkgroep, met aan het hoofd Frans Timmermans, boog zich

131 Het REFIT-platform is een initiatief van de Juncker-commissie onder leiding van Frans Timmermans, waarbij er verschillende belanghebbenden zijn samengebracht (organisaties, bedrijven, academici) om suggesties te doen om Europese regelgeving aan te pakkend die als belastend wordt ervaren. Zie ec.europa.eu/info/sites/info/files/refit_platform_brochure.pdf, bezocht op 26 september 2020.

132 OECD, OECD Regulatory Policy Outlook 2018, Parijs: OECD Publishing 2018, beschikbaar op doi.org/10.1787/9789264303072-en, bezocht op 26 september 2020.

133 De literatuurstudie is een overzicht van 76 papers die sinds 2015 gepubliceerd zijn op het terrein van Better Regulation. De verklaring van de methodologie is te vinden op p. 11-14.

$134 \operatorname{SWD}(2019) 0156$, p. 22-23.

135 Ook kan het zo zijn dat er nog infractieprocedures bij het Europees Hof van Justitie worden aangespannen indien lidstaten incorrect geïmplementeerd hebben. Als er een evaluatieclausule in de wetgeving staat, zal de Commissie hier vermoedelijk niet op wachten.

$136 \operatorname{COM}(2019) 0178$, p. 13.

137 Het rapport is te vinden op ec.europa.eu/commission/sites/beta-political/files/report-task-forcesubsidiarity-proportionality-and-doing-less-more-efficiently_en.pdf, bezocht op 26 september 2020. De reactie van de Commissie is te vinden in COM(2018)0703. 
over drie vragen: (1) Zijn er gebieden waarop de EU (exclusieve) bevoegdheden heeft en die teruggeven zouden kunnen worden aan de lidstaten? (2) Op welke wijze dienen subsidiariteit en proportionaliteit terug te komen in het wetgevingsproces? (3) Op welke wijze kunnen lokale en regionale autoriteiten betrokken worden bij het wetgevingsproces? ${ }^{138}$ Om duidelijk te zijn: dit rapport bevatte niet de door sommigen gedroomde teruggave van bevoegdheden van het Europese niveau naar het niveau van de lidstaten. ${ }^{139}$ Er waren geen duidelijke voorbeelden waar voorheen de EU de bevoegde normsteller was, maar dit nu terug zou kunnen naar een lager niveau. Drie aanbevelingen voor het werkproces uit het rapport: (1) meer aandacht voor subsidiariteit en proportionaliteit door nationale, regionale en lokale overheden beter te betrekken, (2) meer interinstitutionele samenwerking op het gebied van subsidiariteit en proportionaliteit en meer gezamenlijke afspraken hierover, en (3) de grote regeldichtheid aanpakken vanuit het oogpunt van subsidiariteit en proportionaliteit. ${ }^{140}$ De Commissie heeft dertien punten uit het rapport gehaald waarvan zij in haar reactie op het rapport aangeeft deze te zullen meenemen in haar werkproces. ${ }^{141}$ Dit zijn eventueel punten die ook tot een herziening van de beleidsdocumenten ${ }^{142}$ kunnen leiden om meer aandacht voor subsidiariteit en proportionaliteit te genereren. Niettemin is het de vraag of dit rapport en de voornoemde stocktaking exercise daadwerkelijk gaan leiden tot significante aanpassingen.

\subsection{De Commissie-Von der Leyen en de voortgang van het wetgevingsbeleid}

Een eventuele wijziging van de beleidsdocumenten zou wellicht binnenkort kunnen plaatsvinden. De nieuwe Europese Commissie onder leiding van Ursula von der Leyen is gestart per 1 december 2020. Wat al wel bekend is, is dat Maroš Šefčovič, vicepresident van de Commissie en commissaris voor Interinstitutional Relations and Foresight, direct verantwoordelijk gemaakt wordt voor het goedkeuren van de uitzonderingen op de Better Regulation Guidelines. ${ }^{143}$ Ook gaat de Commissie werken met een 'one in, one out'-principe, waarbij wetgeving die lasten met zich brengt pas mag worden vastgesteld als er een vergelijkbare last in hetzelfde beleidsterrein is vervallen. ${ }^{144}$ Hoewel de Commissie-Juncker altijd terughoudend was wat betreft invoering van een dergelijk principe, gaat de Commissie-Von der Leyen hier wel mee starten. ${ }^{145}$ In het werkprogramma van de nieuwe commissie staat aangegeven dat het Better Regulation-beleid onderdeel blijft uitmaken van de prioriteiten van de Commissie. ${ }^{146}$ Aan het eind van 2020

138 Rapport Task Force Subsidiarity and Proportionality, p. 6.

139 Zie ook https://euobserver.com/institutional/143104, bezocht op 26 september 2020.

140 Rapport Task Force Subsidiarity and Proportionality, p. 7.

$141 \operatorname{COM}(2018) 0703$, p. 8-13.

142 Met name de Guidelines en Toolbox.

143 European Commission - Communication from the President to the Commission - The Working Methods of the European Commission, 1 December 2019, P(2019)2.

144 Commissie werkprogramma 2020, $\operatorname{COM}(2020) 0037$, p. 11.

145 Zie hiervoor de studie van het Centre for Economic Policy Science uit 2019, ceps.eu/wp-content/ uploads/2019/12/Feasibility-Study.pdf, p. 97-98, bezocht op 26 september 2020.

146 Commissie werkprogramma 2020, COM(2020)0037, p. 9. 
zal een nieuwe mededeling over Better Regulation verschijnen. ${ }^{147}$ Daarnaast blijkt uit het businessplan van de RSB dat zij door zal gaan met haar huidige werkzaamheden. ${ }^{148}$ Dit betekent dat de Better Regulation Agenda tot op zekere hoogte gewaarborgd zal blijven, en ook het werk van de nieuwe Commissie zal sturen. Interessant zal zijn om te bezien in hoeverre de resultaten uit de stocktaking exercise en andere bronnen worden meegenomen in de nieuwe mededeling die nog moet verschijnen en of dat ook leidt tot aanpassingen aan de beleidsdocumenten zelf.

\section{Conclusie}

Bij de komst van de Better Regulation Agenda in 2015 was er ruimte voor voorzichtig optimisme over de effecten van de samenvoeging van beleidsdocumenten in één coherent pakket. Uiteindelijk bleef wel de vraag welk effect dit zou sorteren. ${ }^{149}$ Bijna vier jaar verder en een proefschrift later kan ik zeggen: het heeft enig effect gesorteerd. Dat effect uit zich vooral op het gebied van meer samenwerking tussen de EU-instellingen, meer kritische controle door de RSB en meer koppeling tussen de ex ante en ex post fase.

Het Interinstitutioneel Akkoord zorgt ervoor dat de EU-instellingen meer samenwerken op het gebied van wetgevingsbeleid. Zo is door de afspraak om gezamenlijk een jaarplanning over wetgeving op te stellen daadwerkelijk meer richting gegeven aan het wetgevende werk van de drie instellingen. Het werk dat wordt verricht om te komen tot één gezamenlijk portaal voor wetgeving (en hopelijk breder voor alle documenten) kan ook een stap in de goede richting zijn. Uiteraard wordt daar het eindproduct van het wetgevingsproces niet ineens beter van, maar het zorgt er op zijn minst voor dat de informatie beter te vinden is. ${ }^{150} \mathrm{En}$ hoewel het geen verdienste is van het nieuwe akkoord, heeft het Interinstitutioneel Akkoord 2003 wel geleid tot een langzame ontwikkeling bij het Parlement en de Raad op het gebied van meedraaien in het wetgevingsbeleid van de Commissie. Het Parlement, met de EPRS als onderzoekscentrum, is hier duidelijk verder in dan de Raad, die slechts zeer recent de mogelijkheid heeft gecreëerd om een impact assessment te laten uitvoeren van zijn eigen amendementen. Uiteindelijk zullen deze ontwikkelingen ervoor zorgen dat het Parlement en de Raad beslagen ten ijs gaan komen in de onderhandelingen over de voorstellen die de

147 Eerst zou dit het tweede kwartaal van 2020 zijn, maar in verband met de Corona-crisis is dit uitgesteld naar later in het jaar. Zie het aangepaste werkplan op ec.europa.eu/info/sites/info/files/ cwp-2020-adjusted-factsheet_en.pdf, bezocht op 26 september 2020.

148 Zie ec.europa.eu/info/law/law-making-process/regulatory-scrutiny-board/regulatory-scrutinyboard-business-plan-2020_en, bezocht op 26 september 2020.

149 Van Golen 2016, p. 307.

150 Of voor Commissiemedewerkers zelf. Tijdens mijn interviews heb ik elke keer de vraag gesteld of zij nog andere IT-systemen of databases gebruikten of dat zij net zoals ik afhankelijk waren van het gebruik van EUR-LEX, EPLO of het documentensysteem van de Raad. Alle medewerkers gaven aan dat zij niet meer hadden dan dat en hun standaard interne netwerk, en dat zij, net zoals ik, gewoon heel vaak Google gebruikten om documenten te achterhalen. 
Commissie onderbouwt met impact assessments. Welke gevolgen dat heeft voor de machtsverhouding tussen de drie instellingen is lastig te overzien op dit moment. Wat wel zeker is, is dat de discussies vermoedelijk iets meer gebaseerd zullen worden op de onderliggende rapporten die de verschillende diensten dan geproduceerd hebben.

De veranderingen in de Commissie zelf zijn na 2015 relatief kleinschalig geweest; de veranderende rol van de RSB als kwaliteitsbewaarder des te meer. Nu evaluaties ook binnen het bereik van de RSB zijn gekomen, zal ook daar door de beleidsdirecties van de Commissie een kwaliteitsslag moeten gaan plaatsvinden, zoals ook is gebeurd toen de voorloper van de RSB, de IAB, voor het eerst impact assessments ging beoordelen (en afkeuren). Dit komt de kwaliteit van evaluaties alleen maar ten goede, en zoals het onderzoek van Stijn van Voorst uitwees is dit ook broodnodig. ${ }^{151}$ Ook op basis van mijn eigen proefschrift heb ik wel enige verbetering gevonden sinds 2015, met name wat betreft de kwantiteit van het gebruik van evaluaties in impact assessments en betere koppeling in het algemeen, maar nog steeds worden veel wetsvoorstellen gepubliceerd zonder impact assessment, bevatten deze lang niet altijd een evaluatie, en als die er wel zijn is deze niet altijd van goede kwaliteit. ${ }^{152}$ Aan de drie fundamentele vereisten voor een goede koppeling - beschikbaarheid, compatibiliteit en de systematische wijze van koppeling - wordt nog niet voldaan in het wetgevingsproces. Ook het eigen onderzoek van de Commissie, de stocktaking exercise, laat zien dat de cyclus nog niet optimaal functioneert.

De Commissie-Von der Leyen zal in het vierde kwartaal van 2020 met een nieuwe mededeling over Better Regulation komen. Wellicht is dat het moment om te bezien hoe het wetgevingsproces verbeterd kan worden en nog meer de nadruk te leggen op de koppeling tussen de twee instrumenten. Uit mijn proefschrift blijkt dat de Commissie er eind 2018 nog niet in is geslaagd die koppeling geheel tot stand te brengen. Wellicht dat in 2020 dan de laatste stap naar een succesvolle koppeling wordt gemaakt.

151 S. van Voorst, Ex-post legislative evaluations in the European Commission: Between technical instruments and political tools, Tilburg: Tilburg University 2018. Het proefschrift is te downloaden op research.tilburguniversity.edu/files/28808242/van_Voorst_Ex_post_19_12_2018.pdf.

152 Het eerste volgt uit onderzoek van het Impact Assessment Institute, A year and a half of the Better Regulation Agenda: what happened?, 2015 (rapport te downloaden op docs.wixstatic.com/ugd/ 4e262e_6b29131f31ad40fd8072fef2b6280bd6.pdf, bezocht op 26 september 2020). Dat laatste blijkt niet zozeer uit mijn proefschrift, maar uit van Voorst 2018. 